Artikel Penelitian

\title{
Hubungan Usia dengan Kedalaman Invasi dan Gambaran Histopatologi pada Penderita Karsinoma Kolorektal di Bagian Patologi Anatomi Fakultas Kedokteran UNAND pada Tahun 2008 sampai 2012
}

\author{
Teddy Kurniawan ${ }^{1}$, Asril Zahari ${ }^{2}$, Aswiyanti Asri ${ }^{3}$
}

\begin{abstract}
Abstrak
Karsinoma kolorektal memiliki angka insiden yang cukup tinggi di Indonesia yang merupakan kanker tersering kedua pada pria dan kanker ketiga terbanyak pada wanita. Kanker ini lebih sering terjadi pada usia lanjut namun juga bisa terjadi pada usia muda. Jenis histopatologi dan kedalaman invasi merupakan beberapa faktor prognostik penting karsinoma kolorektal. Tujuan penelitian ini adalah untuk menentukan hubungan perbedaan usia dengan gambaran histopatologis dan kedalaman invasi dari penderita karsinoma kolorektal di Laboratorium Patologi Anatomi Fakultas Kedokteran Universitas Andalas. Penelitian ini merupakan penelitian retrospektif dengan desain cross sectional study. Data diambil dari hasil pemeriksaan histopatologis pasien karsinoma kolorektal selama periode 2008 sampai 2012. Kemudian dilakukan pencatatan mengenai usia, jenis histopatologis dan kedalaman invasi untuk diuji hubungannya secara statistik. Hasil studi mendapatkan jenis adenokarsinoma musinosa dan karsinoma signet ring cell memiliki persentase yang lebih tinggi pada usia dibawah 50 tahun kebawah dan secara statistik menunjukkan hubungan yang bermakna $p<0,05(p=0,001)$. Karsinoma yang sudah menginvasi lapisan serosa memiliki persentase yang lebih tinggi pada individu diatas 50 tahun, namun secara statistik tidak ditemukan hubungan yang bermakna $(p=0,640)$.
\end{abstract}

Kata kunci: karsinoma kolorektal, usia, histopatologi, kedalaman invasi

\begin{abstract}
Colorectal carcinoma has high incidence rate in Indonesia, which is the second most common cancer in men and the third in women. This cancer is more common in the elderly but can also occur at a young age. Histological type and depth of invasion are important prognostic factors of colorectal carcinoma. The objective of this study was to determine the correlation between age and depth of invasion, histologic type of colorectal carcinoma patients in the department of Pathology Anatomy Faculty of Medicine, Universitas Andalas. This was a retrospective study with crosssectional method. The data was taken from the results of histopathologic examination of colorectal carcinoma patients during the period of 2008 to 2012. The data of age, histological classification and depth of invasion was registered to be analyzed statistically. Mucinous adenocarcinoma and signets ring cell carcinoma had a higher percentage for individuals 50 years and younger and showed statistically correlation at $p<0,05(p=0.001)$. Carcinoma that had invaded the serous layer has a higher percentage in age above 50 , but found no statistically significant correlation $(p=0.640)$.
\end{abstract}

Keywords: colorectal carcinoma, age, histopathologic, depth of invasion

Affiliasi penulis: 1. Prodi Profesi Dokter FK Unand (Fakultas Kedokteran Universitas Andalas, Padang). 2. Bagian Bedah FK Unand. 3. Bagian Patologi Anatomi FK Unand.
Korespondensi: Teddy Kurniawan. Email:

teddykurniawan19@yahoo.co.id,Telp: 085669058446 


\section{PENDAHULUAN}

Insiden karsinoma kolon dan rektum di Indonesia cukup tinggi, demikian juga angka kematiannya dengan perbandingan pria sebanding dengan wanita. Sekitar $75 \%$ ditemukan di rektosigmoid. ${ }^{1}$ Karsinoma ini merupakan karsinoma tersering kedua pada pria $(12,7 \%)$ setelah karsinoma paru $(19,4 \%)$ dan juga merupakan penyebab kematian kedua tertinggi karena karsinoma dengan $11,8 \%$ dari seluruh karsinoma. Sementara untuk wanita, karsinoma ini merupakan karsinoma ketiga terbanyak $(10,5 \%)$ setelah karsinoma payudara $25,5 \%$ dan merupakan penyebab kematian kedua tertinggi dengan $11,8 \%$ dari seluruh karsinoma. ${ }^{2}$ Di Rumah Sakit M. Jamil Padang tercatat 257 pasien karsinoma kolorektal pada periode tahun $2002-2007$. $^{3}$

Berdasarkan penelitian Kurahmawati tahun 2012, usia adalah salah satu faktor yang diduga memiliki pengaruh pada karsinoma kolorektal. Patomekanisme usia dapat menyebabkan karsinoma kolorektal diduga antara lain karena akumulasi mutasi DNA sel penyusun dinding kolon sejalan dengan bertambahnya umur dan juga karena penurunan fungsi kekebalan serta betambahnya asupan agenagen karsinogenik. ${ }^{4}$ Insidensi puncak untuk karsinoma kolorektum adalah usia 60 hingga 70 tahun; kurang dari $20 \%$ kasus terjadi pada usia kurang dari 50 tahun. Bila ditemukan pada usia muda, perlu dicurigai adanya hubungan dengan penyakit lain seperti kolitis ulserativa atau salah satu dari sindrom poliposis. ${ }^{5}$

Gambaran histologi merupakan faktor penting dalam hal penanganan dan prognosis dari karsinoma. Gambaran histopatologis yang paling sering dijumpai adalah tipe adenocarcinoma (90-95\%), adenocarcinoma mucinous (17\%), signet ring cell carcinoma (2-4\%), dan sarcoma $(0,1-3 \%)$. ${ }^{6}$ Penelitian Hamdi tahun 2013 menemukan gambaran histopatologi karsinoma kolorektal yang ditemukan di Laboratorium Patologi Anatomi Fakulatas Kedokteran Universitas Andalas adalah sebagai berikut: adenocarcinoma $(83,46 \%)$, adenocarcinoma mucinous $(11,92 \%)$, signet ring cell carcinoma (1,54\%), undifferentiated carcinoma (0,77\%) danadenosquamous carcinoma $(0,39 \%){ }^{7}$ Gambaran histopatologi juga erat kaitannya dengan derajat diferensiasi dari karsinoma tersebut. Adenokarsinoma bisa ditemukan dalam derajat diferensiasi baik, sedang ataupun buruk. Sementara adenokarsinoma musinosa dan karsinoma signet ring sel dianggap sudah masuk dalam diferensiasi buruk. ${ }^{8}$

Beberapa penelitian sebelumnya juga pernah mengaitkan usia dengan gambaran histopatologi karsinoma kolorektal. Penelitian di kota Osaka, Jepang, mengungkapkan bahwa mucinous carcinoma lebih umum terjadi pada pasien dengan usia 39 tahun kebawah. ${ }^{9}$ Penelitian lain menyebutkan bahwa individu dengan usia dibawah 40 tahun memiliki presentasi yang lebih tinggi untuk mendapatkan mucinous adenocarcinoma, signet ring cell tumor dan carcinoid tumors. $^{6}$ Sementara penelitian oleh Aru W. Sudoyo yang dikutip oleh Ratnasari (2002) menemuka jenis karsinoma kolorektal signet ring cell carcinoma dan mucinous adenocarcinoma lebih banyak ditemukan pada usia muda ( $\leq 40$ tahun) dengan hasil yang signifikan. $^{10}$

Indikator prognostik terpenting karsinoma kolorektum adalah luasnya (stadium) tumor saat diagnosis. The American Joint Commission on Cancer menggunakan klasifikasi TNM. T (Tumor) ditentukan dari seberapa jauh tumor menginvasi jaringan di sekitarnya. $^{5}$ Tingkat awal (T1) merupakan keadaan ketika tumor menginvasi hingga tunika submukosa, sementara pada T4 tumor langsung menginvasi organ atau struktur lain dan/atau menembus viseralis peritoneum. ${ }^{11}$

Beberapa penelitian sebelumnya juga pernah mengaitkan usia dengan kedalaman invasi karsinoma kolorektal. Beberapa studi memperlihatkan bahwa karsinoma kolorektal stadium III lebih sering pada pasien muda, dan stadium II lebih sering pada pasien tua. ${ }^{12}$ Penelitian yang dilakukan di Hungaria juga menemukan bahwa pasien karsinoma kolorektal dibawah 50 tahun memiliki karsinoma kolorektal stadium III dan IV. ${ }^{13}$

\section{METODE}

Jenis penelitian adalah retrospektif dengan desain cross sectional study. Variabel yang digunakan didapatkan dalam waktu yang bersamaan. Diagnosis pasien kolorektal berdasarkan hasil pemeriksaan 
histopatologis. Penelitian ini dilakukan di bagian Lab. Patologi Anatomi FK UNAND dari bulan Mei 2013 sampai Maret 2014. Populasi pada penelitian ini adalah seluruh penderita karsinoma kolorektal yang diperiksa di Lab. Patologi Anatomi FK UNAND tahun 2008 - 2012. Penelitian ini menggunakan total sampling dimana seluruh penderita karsinoma kolorektal pada tahun 2008 - 2012 dijadikan sebagai sampel.

Variabel dependen penelitian adalah jenis histopatologi dan kedalaman invasi karsinoma kolorektal yand dilihat dari data hasil pemeriksaan jenis histopatologi di Lab. Patologi Anatomi FK UNAND. Jenis histopatologi diklasifikan menjadi adenokarsinoma, adenokarsinoma musinosa, karsinoma sel signet ring, karsinoma adenoskuamosa, karsinoma meduler dan karsinoma tidak berdiferensiasi. Sementara kedalaman invasi dibagi menjadi T1, T2, T3, T4 menurut kriteria TNM. Variabel independen penelitian ini adalah usia pasien yang tercatat pada data pemeriksaan jenis histopatologi. Usia pada penelitian ini dibagi menjadi $\leq 50$ tahun untuk usia muda dan $>50$ tahun untuk usia tua. Data dianalisis secara univariat dan bivariat menggunakan uji chi-square dengan derajat kepercayaan $p=0,05$.

\section{HASIL}

Sebanyak 205 data yang tercatat golongan usianya, ditemukan kasus pada usia muda ( $\leq 50$ tahun) sebanyak 87 kasus $(42,44 \%)$, dan usia tua ( $>50$ tahun) sebanyak 118 kasus $(57,56 \%)$. Rata-rata usia pasien adalah 52,88 tahun. Usia paling muda adalah 17 tahun sedangkan paling tua berusia 89 tahun. Jika dibagi dalam rentang 10 tahun, maka terlihat bahwa kasus karsinoma kolorektal terus mengalami peningkatan kasus sampai puncaknya ditemukan pada rentang 51 sampai 60 tahun $(26,83 \%)$. Setelah itu kasus yang ditemukan cenderung menurun.

Pasien berjenis kelamin laki-laki sedikit lebih banyak dibanding perempuan, yaitu sebanyak 105 kasus $(51,22 \%)$.Sementara itu, sebanyak 58 kasus derajat diferensiasi yang ditemukan pada pasien adalah diferensiasi II (49,57\%), jumlah ini tidak jauh berbeda dengan derajat diferensiasi I, yaitu sebanyak 47 kasus $(40,17 \%)$, sementara derajat diferensiasi yang paling sedikit ditemukan pada pasien adalah diferensiasi III sebanyak 12 kasus (10,26\%).

Tabel 1. Distribusi kasus karsinoma kolorektal dalam rentang umur 10 tahun

\begin{tabular}{lcc}
\hline Usia & Jumlah & Persentase (\%) \\
\hline $1-10$ tahun & - & - \\
$11-20$ tahun & 1 & 0,49 \\
$21-30$ tahun & 12 & 5,85 \\
$31-40$ tahun & 34 & 16,59 \\
$41-50$ tahun & 40 & 19,51 \\
$51-60$ tahun & 55 & 26,83 \\
$61-70$ tahun & 42 & 20,49 \\
$71-80$ tahun & 14 & 6,83 \\
$81-90$ tahun & 7 & 3,41 \\
\hline Total & 205 & 100 \\
\hline
\end{tabular}

Hasil studi menemukan tiga jenis histopatologi. Mayoritas jenis histopatologis yang ditemukan adalah adenokarsinoma sebanyak 168 kasus (81,95\%), sisanya adalah adenokarsinoma musinosa sebanyak 31 kasus $(15,12 \%)$, dan karsinoma sel signet ring sebanyak 6 kasus (2,93\%).

Sebanyak 2 kasus $(1,3 \%)$ pada penelitian ini ditemukan karsinoma yang baru menginvasi lapisan submukosa. Sebagian besar karsinoma sudah mengalami invasi sampai lapisan serosa sebanyak 73 kasus $(47,4 \%)$.

Tabel 2. Karakteristik subjek penelitian

\begin{tabular}{lcc}
\hline Karakteristik & $\mathbf{n}$ & $\mathbf{( \% )}$ \\
\hline Usia $(\mathrm{n}=205)$ & & \\
$\quad$ 50 tahun & 87 & 42,44 \\
$\quad>50$ tahun & 118 & 57,56 \\
Jenis kelamin ( $=205)$ & & \\
$\quad$ Laki-laki & 105 & 51,22 \\
$\quad$ Perempuan & 100 & 48,78 \\
Derajat diferensiasi $(\mathrm{n}=117)$ & & \\
$\quad$ Diferensiasi I & 47 & 40,17 \\
Diferensiasi II & 58 & 49,57 \\
Diferensiasi III & 12 & 10,26 \\
Diferensiasi IV & - & - \\
Histopatologi ( $\mathrm{n}=205)$ & & \\
Adenokarsinoma & 168 & 81,95 \\
Adenokarsinoma musinosa & 31 & 15,12 \\
Karsinoma sel signet ring & 6 & 2,93 \\
Kedalaman invasi $(\mathrm{n}=154)$ & & \\
Tis & - & - \\
T1 & 2 & 1,3 \\
T2 & 71 & 46,1 \\
T3 & 73 & 47,4 \\
T4 & 8 & 5,19 \\
\hline
\end{tabular}


Pada Tabel 3, didapatkan bahwa pada kedua golongan usia, lebih sering ditemukan jenis adenokarsinoma. Namun, dari tabel tersebut juga terlihat bahwa gambaran adenokarsinoma musinosa dan karsinoma sel signet ring cenderung lebih sering ditemukan pada golongan usia muda, meskipun jumlah ini masih lebih sedikit dibanding gambaran adenokarsinoma.

Hubungan kedua variabel tersebut diuji signifikansinya secara statistik dengan uji chi-square. Dari uji tersebut didapatkan nilai signifikansi $p=0,001$ sehingga secara statistik pada penelitian ini terdapat hubungan golongan usia dengan jenis histopatologis karsinoma kolorektal.

Tabel 3. Perbandingan golongan usia dengan jenis histopatologis karsinoma kolorektal

\begin{tabular}{llll}
\hline Gol. & Adeno & Adeno & Karsinoma \\
Usia/Jenis & karsinoma & karsinoma & Sel Signet \\
Histopatologi & & Musinosa & Ring \\
& $\mathbf{n}(\%)$ & $\mathbf{n}(\%)$ & $\mathbf{n}(\%)$ \\
\hline$\leq 50$ tahun & $62(71,3)$ & $21(24,1)$ & $4(4,6)$ \\
$>50$ tahun & $106(89,8)$ & $10(8,5)$ & $2(1,7)$ \\
\hline
\end{tabular}

Pada Tabel 4 didapatkan bahwa pada usia tua lebih sering ditemukan karsinoma yang menginvasi lapisan serosa dan invasi ke organ sekitar (54,4\%), dibanding dengan usia muda $(50,7 \%)$. Dari data ini juga dapat dilihat bahwa pada kedua golongan usia, sedikit ditemukan kasus yang baru menginvasi lapisan submukosa.

Tabel 4. Perbandingan golongan usia dengan tingkat kedalaman invasi karsinoma kolorektal

\begin{tabular}{lllll}
\hline Gol. Usia/ & T1 & T2 & T3 & T4 \\
Kedalaman & $\mathbf{n}(\%)$ & $\mathbf{n}(\%)$ & $\mathbf{n}(\%)$ & $\mathbf{n ~ ( \% )}$ \\
Invasi & & & & \\
\hline$\leq 50$ tahun & $1(1,3)$ & $36(48,0)$ & $35(46,7)$ & $3(4,0)$ \\
$>50$ tahun & $1(1,3)$ & $35(44,3)$ & $38(48,1)$ & $5(6,3)$ \\
\hline
\end{tabular}

Hubungan kedua variabel tersebut diuji signifikansinya secara statistik dengan uji chi-square. Dari uji tersebut didapatkan nilai signifikansi $p=0,640$ sehingga secara statistik pada penelitian ini tidak didapatkan hubungan golongan usia dengan kedalaman invasi karsinoma kolorektal.
PEMBAHASAN

Berdasarkan kategori usia, didapatkan bahwa kasus terbanyak ditemukan pada kelompok usia tua (>50 tahun) yaitu sebanyak $57,56 \%$, dan jika usia dibagi dalam rentang 10 tahun, didapatkan jumlah kasus mencapai puncak pada rentang 51 - 60 tahun. Hasil ini sama dengan penelitian sebelumnya di RSUP H. Adam Malik Medan yang menemukan bahwa kelmpok umur tertinggi karsinoma kolorektal adalah usia 50-59 tahun. ${ }^{14}$ Peningkatan inisiden di usia tua dapat terjadi karena akumulasi mutasi somatik yang disebabkan berkembangnya neoplasma dan juga faktor penurunan imunitas seiring bertambahnya usia. ${ }^{5}$

Pada penelitian ini juga ditemukan kasus pada usia yang lebih muda, yaitu 17 tahun. Menurut kepustakaan, karsinoma yang muncul sebelum usia 40 tahun, biasanya terjadi bersama sejumlah faktor risiko lain, terutama familial. ${ }^{15}$

Gambaran histopatologi terbanyak pada penelitian ini adalah adenokarsinoma sebanyak 168 kasus $(81,95 \%)$. Beberapa penelitian sebelumnya di Pontianak, Medan dan Padang juga menemukan hal yang sama. ${ }^{7,14,16} \mathrm{Hal}$ ini berkaitan dengan lesi awal pada kolon yang sering berubah menjadi adenokarsinoma, salah satunya Chron's disease. Keseluruhan insiden dari adenokarsinoma yang muncul pada penyakit Chron's disease adalah sekitar $20 \%{ }^{15}$

Berdasarkan kedalaman invasi, sebagian besar kasus yang ditemukan mengalami invasi sampai ke lapisan serosa $(47,4 \%)$, hanya sebagian kecil karsinoma yang baru menginvasi lapisan submukosa (1,3\%). Penelitian sebelumnya di RSUP Hasan Sadikin Bandung, juga mendapatkan kasus terbanyak adalah karsinoma yang sudah mencapai lapisan serosa $(20,2 \%)$. Kasus ini sedikit lebih banyak dari kasus karsinoma yang baru mencapai lapisan muskularis (19\%). Sementara sedikit sekali $(0,8 \%)$ ditemukan karsinoma yang baru mencapai lapisan submukosa. ${ }^{17} \mathrm{Hal}$ ini disebabkan karsinoma kolorektal biasanya tidak memberikan gejala dan tanda khas pada tahap awal. Pasien baru datang apabila sudah terjadi gejala yang pada umumnya gejala tersebut timbul karena penyulit, misalnya tidak bisa defekasi ataupun perdarahan saat defekasi. ${ }^{11}$ 
Analisis usia dengan jenis histopatologis memperlihatkan adenokarsinoma musinosa dan karsinoma sel signet ring memiliki persentase yang lebih tinggi pada usia muda $(28,7 \%)$ dibanding yang ditemukan pada usia tua $(10,2 \%)$. Berdasarkan hasil analisa statistik pada penelitian ini, didapatkan hubungan antara usia dengan jenis histopatologis $(p=0,001)$. Hasil tersebut sama dengan penelitian sebelumnya yang dilakukan di Amerika Serikat pada tahun 1999 - 2001 dan penelitian yang dilakukan di tiga rumah sakit, yaitu Jakarta, Makasar, dan Bandung tahun 2010. ${ }^{6,18}$

Persentase adenokarsinoma musinosa dan karsinoma sel signet ring yang lebih tinggi pada usia muda ini bisa terjadi karena adanya perbedaan patogenesis. Adenokarsinoma musinosa dan karsinoma sel signet ring biasanya merupakan karsinoma dengan jalur instabilitas mikrosatelit, dimana jalur ini pada beberapa penelitian sebelumnya lebih sering ditemukan pada pasien muda yang biasanya berhubungan dengan herediter. Selain itu, perbedaan Persentase Ini Juga Berpengaruh Pada Prognosis karsinoma pada usia muda karena karsinoma sel signet ring dan adenokarsinoma berhubungan dengan prognosis yang lebih buruk dan secara derajat diferensiasi juga ditetapkan dalam derajat diferensiasi III. ${ }^{9,18}$

Pada analisis bivariat usia dengan kedalaman invasi secara statistik, tidak ditemukan hubungan yang signifikan antara usia dengan kedalaman invasi $(p=0,640)$. Namun, terlihat kecenderungan kelompok usia tua memiliki persentase yang sedikit lebih tinggi untuk karsinoma yang sudah menginvasi sampai lapisan serosa dan invasi ke organ sekitar (54,4\%) dibanding usia muda $(50,7 \%)$. Hal yang sama juga dijelaskan pada penelitian sebelumnya di Istambul. Pada penelitian tersebut juga dijelaskan bahwa meskipun terdapat perbedaan persentase kedalaman invasi pada usia muda dan usia tua, namun hal tersebut tidak berhubungan secara signifikan $(p=0,712) .^{19}$

Hal yang lebih berpengaruh pada perburukan prognosis karsinoma kolorektal di usia muda jika dikaitkan dengan stadium adalah adanya keterlibatan kelenjar limfe regional. Kejadian karsinoma kolorektal yang melibatkan kelenjar limfe lebih tinggi pada pasien usia muda dibandingkan dengan usia tua untuk semua kategori kedalaman invasi. $^{20}$ Penelitian sebelumnya juga memperlihatkan bahwa karsinoma kolorektal stadium II lebih sering pada pasien tua, dan stadium III lebih sering pada pasien muda. ${ }^{16}$ Ada juga yang menyebutkan pasien dibawah 50 tahun cenderung memiliki karsinoma kolorektal pada stadium III dan IV, yang artinya sudah melibatkan kelenjar limfe regional dan juga metastasis. ${ }^{12}$

\section{SIMPULAN}

Jenis adenokarsinoma musinosa dan karsinome sel signet ring paling sering ditemukan pada usia muda. Namun secara statistik tidak ditemukan hubungan bermakna antara usia dan gambaran histopatologi.

Pada kelompok usia tua, karsinoma yang ditemukan cenderung sudah mencapai lapisan serosa dan invasi organ sekitar. Namun secara statistik tidak didapatkan hubungan bermakna antara usia dengan kedalaman invasi.

\section{DAFTAR PUSTAKA}

1. Riwanto I, Hanami AH, Pieter J, Tjambolang $\mathrm{T}$, Ahmadsyah I. Usus halus, appendiks, kolon, dan anorektum. Dalam: Sjamsuhidajat R, Karnadiharja W, Prasetyono TOH, Rudirman R, editor (penyunting). Buku ajar ilmu bedah.Edisi ke-3. Jakarta: EGC; 2007.hlm.774 - 80.

2. Globocan 2008. Indonesia. (diunduh 5 Mei 2013). Tersedia dari: URL: HYPERLINK http://globocan. iarc.fr/factsheet.asp\#KEY

3. Zahari A. Deteksi dini, diagnosa, dan penatalaksanaan kanker kolon dan rectum. Majalah Kedokteran Andalas. dalam Rangka Dies Natalis 53 FK UNAND. 2008. Suppl:102.

4. Kurahmawati A. Hubungan karakteristik (usia dan jenis kelamin) dan kadar trigliserida serum dengan kejadian karsinoma kolorektal di RSUP dr. Kariadi Semarang (skripsi). Semarang: Universitas Diponegoro; 2012.

5. Crawford JM, Kumar V. Rongga mulut dan saluran gastrointestinal. Dalam: Ramzi S, Cotran, Robbins SL, editor (penyunting). .Buku ajar patologi.Vol. 2. Edisi ke-7. Jakarta: EGC;2004.hlm.653 - 6. 
6. Steward SL, Wike JM, Kato I, Lewis DR, Michaud F.A population-based study of colorectal cancer histology in the United States 1998 - 2001. Pubmed. 2006;107(5):1128 - 41.

7. Hamdi M. Profil carcinoma colorectal di laboratorium Patologi Anatomi Fakultas Kedokteran Universitas Andalas periode Januari 2009 - Desember 2011 (skripsi). Padang: Fakultas Kedokteran Universitas Andalas;2013.

8. Hamilton SR. Rubio CA, Vogelstein B, Sobin LH, Kudo S, Fogt $F$, et al. Carcinoma of the colon and rectum. Dalam: Hamilton SR, Aaltonen LA, editor (penyunting). Pathology and genetics of tumours of the digestive system.Lyon: IARC Press; 2000.hlm. $105-10$.

9. Okuno M, Ikehara T, Nagayama M, Kato Y, Yui S, Umeyama K. Mucinous colorectal carcinoma: clinical pathology and prognosis. Pubmed. 2003; 54(11):681 -5.

10. Ratnasari D. Perbedaan derajat diferensiasi adenokarsinoma kolorektal pada golongan usia muda. baya. dan tua di RSUP dr. Kariadi Semarang (skripsi). Semarang: Universitas Diponegoro; 2002.hlm.9.

11. Desen W, Japanes W. Onkologi klinis Fakultas Kedokteran Universitas Indonesia. Jakarta: Balai Penerbit Fakultas Kedokteran Indonesia; 2008. hlm. $423-8$.

12. Mitry E, Benhamiche AM, Jouve JL, Pharm FC, Faivre CF, Faivre J. Colorectal adenocarcinoma in patients under 45 years of age: Comparison with older patients in a well-defined french population. Disease of The Colon \& Rectum. 2001; 44(3): $380-7$.
13. Banai Z, Bartók Á, Renteria-Delgádó RZ Colorectal carcinoma under the age of 50 years. Pubmed. 2013;154(34):1345 - 51.

14. Ramachandaram A. Gambaran kelompok usia dan jenis histopatologi pada pasien kanker kolorektal di RSUP H. Adam Malik Medan dari Juni 2008 hingga Desember 2009 (skripsi). Medan: Universitas Sumatera Utara; 2009. hlm. 9 - 11.

15. Brunicadi FC, Andersen DK, Billiar TR, Dunn DL, Hunter JG, Pollock RE. Schwartz's principles of surgery. Edisi ke-8. New York: The McGraw - Hill Companier; 2007.hlm.1073 - 75.

16. Yusra CA. Gambaran pasien kanker kolorektal di RSUD dr. Soedarso Pontianak periode tahun 2006 - 2010 (skripsi). Universitas Tanjungpura; 2012. hlm.10.

17. Sander MA. Profile of colo-rectal cancer at Hasan Sadikin Hospital Bandung. Jurnal Keperawatan. 2012;3(1):9- 21.

18. Sudoyo AW, Hernowo B, Krisnuhani E, Reksodiputro AH, Hardjodisastro D, Sinuraya ES. Colorectal cancer among young native Indonesians: a clinicopathological and molecular assessment on microsatellite instability'. Medical Journal of Indonesia. 2010;19(4):245 - 51.

19. Alici S, Aykan NF, Sakar B, Bulutlar G, Kaytan E, Topuz E. Colorectal cancer in young patients: characteristics and outcome. The Tohoku Journal of Experimental Medicine. 2003;199(2):85 - 93.

20. Sitzler PJ, Seow-Choen F, Ho HY, Leong APK. Lymph node involvement and tumor depth in rectal cancers. Disease of The Colon \& Rectum. 1997; 40(12):1472 - 6 . 